\title{
Rural Free Delivery In Hardin County
}

Wayne E. Fuller

THE FREE DELIVERY OF MAIL SERVICE urban Americans know today began in 1863. First authorized in that year by Congress for cities with a population of 50,000 or more, it was extended over the years until by 1890 daily mails were being delivered free in towns with no more than 10,000 inhabitants. In spite of this extension of the service, scarcely more than 19,000,000 Americans out of a population approaching $62,000,000$ in that year had their mail delivered to their doors. Elsewhere, in the little villages of rural America and on the farms across the nation, people still received their mail at their post offices, and the observation of one journalist in 1890 that "there had been no improvement in the postal system in rural America for a hundred years," was no exaggeration. ${ }^{1}$

In the rural America of 1890, going to the post office for the mail was a part of the farm chores. It might mean a trip of one, two, or perhaps ten miles, and the amount of time it consumed in one year was enormous. Worse still, since the average farmer could go for the mail only once or twice a week, he rarely subscribed to a daily newspaper, and his news, usually a week old, came to him through his county weekly. He had neither daily market nor daily weather reports, and

${ }^{1}$ Rodney Welch, “The Farmer's Changed Conditions," The Forum $\mathrm{X}$ (Feb., 1891), 699; for the general treatment of rural free delivery of mail see RFD: The Changing Face of Rural America (Indiana University Press, 1964). I am indebted to the University Research Institute of the University of Texas at El Paso for various research grants which allowed me to do research in the County Rural Free Delivery papers in the National Archives in Washington, D. C., and to the Iowa Historical Society for the use of its newspaper file. 
the average amount of mail he received in a week was pitifully small.

Perhaps because they could visualize no practical substitute for their antiquated postal system, farmers had never really demanded a change in their mail service before 1891 . But in that year, when President Benjamin Harrison's Postmaster General, John Wanamaker, suggested the feasibility of extending the free delivery service to the countryside, farmers, already sensitive to government discrimination and noting the great discrepancy between the government's city delivery service and their own, began to agitate for rural free delivery of mail.

Perhaps in no state of the Union was the rural free delivery idea more popular than it was in Iowa. The Ottumwa Courier declared in 1891 that "Postmaster General Wanamaker, if he succeeds in getting free daily delivery of mail to the farmers will be as popular among the agrestic classes as Secretary Rusk," the man President Harrison had made the nation's first Secretary of Agriculture. And early in 1892, after a rural delivery bill had been introduced in Congress, the Sac City Sun, as did a number of other Iowa newspapers, gave the project its blessing. "A bill has been introduced in Congress appropriating an amount to be used for the free delivery of mail in the country," it said. "This seems like a move in the right direction. If the farmers could have their mail delivered at their homes every day it would effectually cure the desire of many to abandon the farm and move to town."

Iowa's farm organizations also gave the proposal vigorous support, and Iowa Congressmen, back in Washington for the session of Congress beginning in December, 1891, were receiving scores of petitions from such organizations as the Algona Grange, the "Live and Let Live Grange," the Oak Ridge Grange, and many others, all pleading for the establishment of rural free delivery. ${ }^{3}$

Pressed by their constituents, Iowa Congressmen went on record in favor of rural delivery. John Hull of Des Moines

${ }^{2}$ As quoted in "Free Delivery Service," Sen. Doc. No. 92, 52 Cong., 1 Sess., 100 and 151.

${ }^{3}$ Congressional Record, 52 Cong., 1 Sess., 1582, 1803, 2886. 
spoke for it, but of far greater importance was David B. Henderson's support for the proposal. By 1892 Henderson had represented Iowa's third district in Congress for ten years, and in that time he had become a person of considerable influence. He was a member of the House Committee on Post Office and Post Roads and would within a few years be the Speaker of the House. A man not readily given to taking up new ideas, his support of rural delivery might have angered and surprised some of his colleagues, but his position, as he explained it, was completely logical. For it was his view that if the government was to continue the policy of delivering the mail in the cities, and he had no doubt it would, then in justice to everyone, it would eventually have to deliver the mail in the country as well. ${ }^{4}$

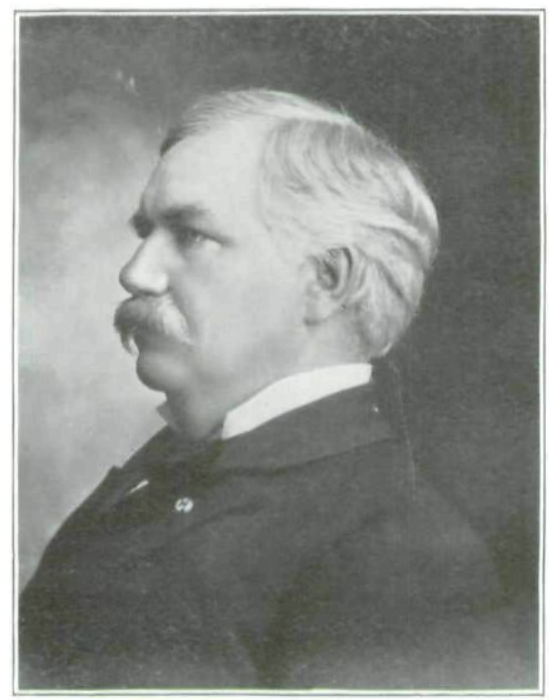

Department of History and Archives

David B. Henderson

The greatest obstacle to establishing a system of rural free delivery was, of course, the anticipated cost. How much it would cost was anyone's guess in 1892, but estimates ran as high as $\$ 20,000,000$ a year, and the first rural delivery bill ever presented in Congress carried with it an appropriation

${ }^{4}$ Ibid., 4875-76; on Henderson see Louis Bernard Schmidt, "David B. Henderson," Dictionary of American Biography ed. Allen Johnson and Dumas Malone (22 vols.; New York, 1928-1944), VIII, 527-29. 
for $\$ 6,000,000$. But Henderson, frugal man that he usually was, refused to be perturbed about the prospective cost of rural delivery. "Now the question of expense is not a matter that should deter us from action on this matter," he told the members of the House.

The question of how much to spend is always in order. But that this thing should be done there is no doubt in my mind. The farmers, as I view it now, are not getting the full share of the benefits from our postal appropriations. They are feeders to the great funnel, as well as any of us, and will become more active feeders if allowed to enjoy the benefits. ${ }^{5}$

In spite of Henderson's efforts and petitions from farmers across the country, rural free delivery was not established that year, nor for the next four years, so controversial a proposition was it. Not until 1896 was free delivery to the farmers tried, and then only as an experiment that seemed predestined to fail.

Between the autumn of 1896 and the autumn of 1897 , 82 experimental rural delivery mail routes were established in widely scattered areas of the nation in order to test the service under as many different conditions as possible. Of those first experimental routes, four were located in Iowa: three at Morning Sun in Louisa County, and one at New Providence in Hardin County. ${ }^{6}$

Like most of the experimental routes across the nation, those in Iowa were completely successful, and by 1898 the Post Office Department had begun to broaden the experiment. That year the Department announced that farmers interested in obtaining rural free delivery should petition their Congressman for a rural mail route, and if their Congressman approved and certain other conditions were met, the Department would establish the route. This announcement was almost immediately followed by thousands of rural route petitions from anxious farmers who wanted their mail delivered, and within a year the establishment of rural routes became a large-scale business. Finally, in 1902, after six years of experimentation, Congress made rural delivery a permanent

${ }^{5}$ Cong. Record, 52 Cong., 1 Sess., 4876.

${ }^{6}$ Postmaster General's Report, 1897, 104; see also Mary C. Ludwig, "Beginnings at Morning Sun," The Palimpsest, XXX (May, 1949), 142-48. 
part of the postal system. ${ }^{7}$

In the first years of the experiment, rural mail routes were established singly throughout the country, one here, one there, in a kind of helter-skelter fashion, following quite closely the roads and patterns suggested by the petitioning farmers. But in 1899 the Post Office Department began an experiment in Carroll County, Maryland, in which rural mail routes were dove-tailed together and laid out in such a fashion as to cover the entire county. A mass of statistics was gathered from this experiment which proved, at least to the satisfaction of the postal officials, that rural delivery established over a wide area was an entirely satisfactory mail system. ${ }^{8}$ The most important by-product of the experiment, however, was not the statistics but the demand it created among other counties across the nation for county rural delivery systems, and one of the first counties to request such a system was Hardin County, Iowa.

By the summer of 1900 rural routes had been established in Hardin County at Eldora, New Providence, Hubbard, Steamboat Rock, and Union, and petitions for other mail routes had been filed from Ackley, Iowa Falls, Alden, Radcliffe, and Whitten.

"There is," said William Boylan, postmaster at Hubbard, "a wonderful demand for rural free delivery all over the county at present, but it is not probable that Hardin County will get any more routes established at present, for this county has now more routes than almost any other county in the state of like population."

But at the same time Postmaster Boylan was predicting no more routes for Hardin County, he was doing everything in his power to bring more routes to the county. For he and the postmasters of the nine other post offices where rural

${ }^{7}$ Postmaster General's Report, 1898, 155, 246, and Statutes at Large of the United States, XXXII (1902), 164.

${ }^{8}$ "Rural Free Delivery in Carroll County, Maryland," House Doc., No. 691, 56 Cong., 1 Sess., 1-12.

'Postmasters' Petition for County Free Delivery, Hardin County, Ia., n. d., in Hardin County File, Rural Mail Service, County Files, Post Office Records, National Archives, Washington, D. C. Hereafter referred to as Hardin County File, N. A.; The [Eldora, Hardin County] Herald, Aug. 11, 1900. 
routes had already been established or where rural route petitions were on file, had signed a petition asking that their entire county be blanketed with rural routes as had been done in Carroll County, Maryland.

The postmasters presented admirable arguments for establishing rural free delivery in their county. "Hardin County," said their petition:

is the ideal county of the Mississippi Valley to test the practicibility [sic] of delivering the mail to every rural home possible. Hardin County has not a saloon within its borders. Hardin County has borne the distinguished honor of having the smallest per cent of illiteracy of any county in the nation. It is the exception to find a home without a newspaper and other valuable reading matter. The rural population is progressive, intelligent, and wants free mail.

What the postmasters hoped for, according to their petition, was "that Hardin County . . . be made the objective county of the West for the fullest test of the Rural Free Delivery Service, as is being done for the East in Carroll County, Maryland." 10

The postmasters were wise enough not to send their petition directly to the Post Office Department. Instead they relied upon Charles E. Albrook, a local politician from Eldora, to direct their request into the proper channels, and the backstage political maneuvering that brought county rural delivery to Hardin County was part of a pattern that was to be repeated again and again in the establishment of county free delivery systems throughout the Midwest.

Charles Albrook was born in Pennsylvania, raised in Iowa, and graduated from Cornell College. Like so many of the nation's politicians of the Nineteenth Century he began his career teaching in a country school and studying law. By 1900 he was a practicing attorney in Eldora, county seat of Hardin County, and also chairman of the County Central Committee of the Republican party. In June, at the Republican state convention he had nominated David B. Henderson for Congressman from Iowa's third district, and praised him lavishly saying that because of him "we stand second to no state in the union in the influencing and the shaping of the

\footnotetext{
${ }^{10}$ Postmasters' Petition, Hardin County File, N. A.
} 
legislation of this great and prosperous country."11

Albrook was, of course, referring to the fact that Henderson had been since the previous year, and, if all went well, would be again, the Speaker of the House of Representatives. Such a man, highly placed and perhaps somewhat indebted to Albrook for his nominating speech, was in a strategic position to secure county rural delivery for Hardin County, and Albrook did not hesitate to ask for help. Forwarding the postmasters' petition to Henderson on August 3, 1900, he requested the Congressman to send it on to the Post Office Department with a strong recommendation. He wrote:

I know that no one could aid us with as good results as yourself, and I assure you anything you may do will be appreciated. ... I beg pardon for arguing the matter as strongly as I do but I do so, feeling that the effort put forth, if successful, will be of some advantage to you, to myself, and of great advantage to your constituents in this particular part of your district..$^{12}$

Despite the prospective advantages county delivery might bring him, Congressman Henderson was somewhat reluctant to support Albrook's proposal. He did not immediately forward the Hardin County postmasters' petition to the Post Office Department, and possibly did not even answer Albrook's first letter. At any rate, one week after he had first written him, Albrook again wrote Henderson urging him to give the postmasters' petition his "usual ardent support."13

At last, on August 16, Henderson wrote the First Assistant Postmaster General, almost apologetically, saying that though he believed in giving counties that had no rural free delivery at all a fair share before establishing the system completely over any one county, still he felt obliged to submit the Hardin County proposal for the Department's careful consideration because Albrook, as he put it, was "a man of such high character and ability. ..." But when a few days later the Superintendent of Free Delivery wrote telling him to apply directly to the Postmaster General for county delivery in Hardin County, Henderson lost his timidity. "I most respectfully ask," he wrote Postmaster General Charles E. Smith, "and

${ }^{11}$ William J. Moir, ed., Past and Present of Hardin County, Iowa (Indianapolis, 1911), 184; The Herald, June 30, 1900.

${ }^{12}$ C. E. Albrook to D. B. Henderson, Aug. 3, 1900, Hardin County File, N. A.

${ }^{13}$ Ibid., Aug. 10, 1900, Hardin County File, N. A. 
earnestly recommend complete Rural Free Delivery service for Hardin County, Iowa. ... ." On September 11, less than two weeks after he had written the Postmaster General, Henderson learned that the Postmaster General had that day ordered complete rural delivery service for Hardin County. ${ }^{14}$

While this correspondence was being carried on, the farmers were clamoring for rural mail routes. "Hundreds of Hardin County farmers," said The Herald, the Eldora semiweekly newspaper, "are asking the question "When will the rural free delivery of mails be extended? When will a route be laid out my way?" "15 But though Albrook and a few others knew by September 11, or shortly thereafter, that the county was to have rural delivery, no public announcement to this effect was made. As chairman of the County Central Committee of the Republican party, Albrook was energetically engaged in a political campaign, not, according to The Herald, because "the least fear of defeat is felt," but "in order to get every voter to the polls." In early August, having gone to Canton, Ohio, as one of the delegates to notify President McKinley of his renomination for the presidency, Albrook had returned to step up his campaign. "The Herald remarks," ran a new item in late September, "that Chairman Albrook of the Republican Central Committee will leave notbing [sic] undone to get out a full party vote Nov. 6."16

Perhaps it was in keeping with his plan to "leave nothing undone to get out a full party vote" that predisposed Albrook to withhold the announcement that rural delivery was to be established on a county-wide basis in Hardin County. In any event, it was not until October 31, in the next to the last issue before the election, that The Herald's banner headline announced that Hardin County had been selected for county rural delivery. "The order means," exclaimed The Herald triumphantly,

that Hardin County will be made the model county of the

${ }^{14}$ D. B. Henderson to Acting First Assistant Postmaster General, Aug. 16, 1900; Superintendent of Free Delivery to D. B. Henderson, Aug. 28, 1900; D. B. Henderson to Charles Emory Smith, Postmaster General, Aug. 30, 1900; Acting First Assistant Postmaster General to D. B. Henderson, Sept. 11, 1900, Hardin County Files, N. A.

${ }^{15}$ The Herald, Sept. 4, 1900.

${ }^{16}$ Ibid., July 25, Aug. 8, and Sept. 22, 1900. 
state, and every farmer as near as practicable will be given the benefits of free mail. . . . Every well informed person is advised that rural free delivery is yet in the experimental stage. ... To further test the system the department of rural free delivery had had under consideration the plan of giving one county in each state complete service from every post office of importance. The plan is to establish a model system in such county and rigidly test every detail of the service. The department decided to act, and here is where Hardin county comes in as a winner. . . . In all that is good Hardin county deserves the best. She has the best congressman in Speaker David B. Henderson in the national capital, and will have the best rural free delivery in the union. ${ }^{17}$

In the election that followed on the heels of this announcement the Republicans won a smashing victory in Hardin County, and, though nothing was said directly about the part county rural delivery may have played in the results, The Herald's praise of Charles Albrook's role in the campaign inferred the value of the announcement. "The Herald," ran a post-election story,

as a republican newspaper would be derelict of its duty did it not say a word concerning the work of Chas. E. Albrook, as chairman of the Hardin County republican central committee. The grand and sweeping victory in this county shows that those who had the campaign in charge have by no means been idle or 'sleeping on on their arms' so to speak. . . . It can be truthfully said that there has been no campaign conducted in a more intelligent and educational way than this, and the republican party of this county owes much to Mr. Albrook for the grand and satisfactory victory won at the polls last Saturday." 18

At the time of the announcement The Herald had no information regarding the date that the county rural delivery service would actually begin but speculated that it might not be for two or three months. In this the newspaper was unduly optimistic, for as it turned out, the work of establishing rural delivery in Hardin County was beset with innumerable difficulties, as it was wherever county systems were organized, and was not completed for almost a year.

One of the first problems confronting the Post Office Department in Hardin County was the selection of the man to map out the county, lay out the routes, choose the roads over which the routes would run, and select the post offices

${ }^{17}$ Ibid., Oct. 31, 1900.

${ }^{18}$ Ibid., Nov. 10, 1900. 
from which the routes would begin. In the more than three years since the first experimental rural mail routes had been established the Post Office Department had employed and trained a number of men, usually referred to as special or rural agents, to do this work. Most of the men selected were faithful supporters of the Republican party, but though they were largely political appointees, they were nonetheless usually competent, tactful, and patient men doing a job that required these virtues above all else. ${ }^{19}$.

By chance, one of the men employed and trained by the Department for this work was John T. Boylan, a Hardin County man and co-editor of The Herald at Eldora. Perhaps Boylan was also a good friend of Charles Albrook; in any case, Albrook, for whatever reason, wanted Boylan to lay out the rural free delivery system in Hardin County and urged Congressman Henderson to have the Post Office Department assign Boylan the job. The request was relayed to the Department, but the postal officials hesitated to comply. ${ }^{20}$

To the casual observer it might have appeared logical for the Department to permit its agents to lay out routes in their home counties. But such were the problems, particularly in establishing free delivery over an entire county, that the Department normally forbade its agents to organize routes in their own counties. In fact, Boylan himself had been placed in charge of a district far removed from Hardin County in July, 1900, presumably because, as The Herald suggested, he could do his best work among the people he did not know. ${ }^{21}$

How long the question of Boylan's appointment delayed the beginning of the work in Hardin County is uncertain. Congressman Henderson wrote a sharp letter to the Department in late November, 1900, complaining because Boylan had not been appointed to lay out the service by that time; but in reply, the Department made no mention of Boylan's appointment and said only that it would begin work in the

${ }^{19} \mathrm{On}$ the political nature of the rural agent see the Cong Record, 55 Cong., 2 Sess., $2938 \mathrm{ff}$.

${ }^{20}$ The Herald, July 7, 1900; D. B. Henderson to W. M. Johnson, First Assistant Postmaster General, Nov. 21, 1900, Hardin County File, N. A.

${ }^{21}$ The Herald, Aug. 8, 1900. 
county after the first of the year. After the first of the year, however, there were more delays, and it was not until May that the Department sent Special Agent A. B. Smith, not Boylan, to establish free delivery in Hardin County. ${ }^{22}$

Smith arrived in Eldora on May 21, 1901. Finding no maps of the county that could be used for laying out rural mail routes, he worked for nearly three days preparing maps he could use in his work. On May 23 he began the arduous process of traveling over the county locating on his maps the schoolhouses, bridges, houses, and churches along the roads and selecting suitable roads for the mail carriers to travel over. He visited the county's post offices, talked to the farmers and the small-town businessmen, and tried to decide just where the routes would run, from what post offices they would begin, and what post offices could be eliminated. ${ }^{23}$

Hardin County, as Smith found it in 1901, was a county of prosperous farmers. "The people," he wrote, "are as a class well to do; the vast majority own their own farms and live in good style. There are many really elegant farm houses, and I do not know that I have seen more than a dozen houses in the county that could be deemed other than comfortable." Smith was particularly impressed with the farmers' interest in education. "I know of no community where more daily papers are read. School houses abound and education is well-nigh universal," he wrote. He did, nonetheless, find some shiftless farmers, but attributed their laziness to the county's soil which was so rich it grew crops with only the slightest cultivation. ${ }^{24}$

The principal crops grown in the county, according to Smith's report, were oats, corn, and hay. Large herds of cattle were being raised along the streams, but Hardin County was above all the "home of the hog." "I am satisfied," he wrote, "that there are more hogs in Hardin County than in

${ }^{22}$ D. B. Henderson to W. M. Johnson, Nov. 21, 1900; W. M. Johnson to D. B. Henderson, Dec. 4, 1900; Report of Special Agent A. B. Smith on Hardin County, Sept. 30, 1901, Hardin County File, N. A.; Agent Smith's report hereafter referred to as Smith's Report on Hardin County.

${ }^{23}$ Smith's Report on Hardin County.

${ }^{24}$ Ibid. 
any other county in the state."25

Smith found the farmers eagerly awaiting the delivery of their mail to their farms and very cooperative, particularly in the purchase of rural mailboxes. Elsewhere in the nation farmers were often reluctant to spend money for the kind of mailboxes the Post Office Department recommended, preferring to put up syrup cans or makeshift affairs to hold their mail. But the Hardin County farmers, Smith said, "did not hesitate when called upon to purchase boxes; they want the best and the higher the price the better it suits them." ${ }^{\text {"26 }}$

Smith's most uncomplimentary remarks regarding Hardin County were reserved for the county's roads. Traversing the length of the county diagonally from the northwest to the southeast was the Iowa River. Several iron bridges crossed the river, and for that reason Smith believed the river itself would not prove to be too great an obstacle in laying out the routes. But the country roads were another matter. Nearly all of them were graded; sloughs were filled and so were the marshes, and in summer Smith believed they were as good as any in the nation. But only a few of the roads were graveled and Smith warned that the carriers "must expect to contend with a great deal of mud" in the spring in spite of his best efforts to run the rural routes around the worst roads. ${ }^{27}$

Smith continued to travel the county into June, but by this time he was apparently running into the same troubles that were to perplex so many special agents as they tried to establish rural free delivery in the counties of the nation.

It was never easy to go into a rural community and lay out a mail route that would please everyone. Once a route was established, some farmers complained because it did not run directly past their farms and thereby forced them to go a quarter of a mile or so to a crossroads to get their mail; others objected when they were placed last on their mail carrier's line of travel and received their mail in the afternoon instead of the morning. But the most vigorous com-

${ }^{25}$ Ibid.

${ }^{26}$ Ibid.

${ }^{27} \mathrm{Ibid}$. 
plaints against the way the mail routes were established did not come from the farmers at all. They came instead from rural America's small town businessmen who, believing that where a farmer's postal address was there also would be his trade, wanted all rural routes to begin in their particular towns; they came predominantly, however from the local postmasters who either did not want rural delivery at all or also wanted to make sure that the mail routes which were established would emanate from their post offices.

The rural postmaster's point of view was easy to understand. Until rural free delivery came along, his position had been secure. His little post office did all the farmer's postal business: for every letter the farmer sent, the postmaster received a cancellation fee and also received a rental fee for every mailbox in his post office. Neither of these fees amounted to much, but many a country postmaster, whether his post office was in a village or small town or simply located at some wide place in the road, had a store attached to his post office and his post office drew trade to the store. It was this, plus the prestige and dignity that went with the position, that made the postmastership attractive to the enterprising rural American.

But when the free delivery mail routes began pushing through the countryside, they revolutionized the old mail system. They displaced the star route mail carriers who had always carried the mail from the railroad stations to the little post offices in the hinterland, and more importantly, they began to displace the little post offices themselves. For one rural route twenty-four miles long, bringing the mail to all the farmers within an area twenty miles square, eliminated the need for all except one of the post offices within that region, and the Post Office Department quickly established the policy of abolishing all post offices made useless by the new mail service. ${ }^{28}$

This policy, however, was honored almost as much in the breech as in the observance. For postmasters whose offices were about to be eliminated fought bitterly to save their post offices. They cajoled and argued and threatened, trying first

${ }^{28}$ Postmaster General’s Report, 1901, 11-12. 
one way then another to get the special agent laying out routes to let their offices alone. If this failed they circulated petitions among their friends and neighbors, some of them fraudulent, demanding the retention of their post office. And if need be, they could, since most of them were local politicians, prevail upon their friends in Congress to present their cases to the Post Office Department. When this happened, Congressmen were unhappily torn between farmers who wanted rural routes, postmasters who wanted to retain their post offices, and the Post Office Department that in theory at least said they could not have both. In the end, the Post Office Department often ended by leaving the little post offices, at least temporarily, and running rural mail routes by them. ${ }^{29}$

The special agent's confrontation with angry postmasters was bad enough when he was establishing only one or two routes in a locality that threatened the existence of only one or two post offices. But it was almost overwhelming when he laid out enough rural routes to cover an entire county. For then he must make recommendations calling for the closing of a large number of superfluous post offices and star routes and this almost inevitably resulted in a concentrated attack upon him and his works by a phalanx of angry postmasters and star route mail carriers.

This was Special Agent Smith's predicament in Hardin County. Traveling through the county, visiting post offices and postmasters and drawing plans for one rural mail route here and another there, Smith became convinced that a number of the county's little post offices could be eliminated. The post office at Abbott, for example, located on the Iowa Central railroad about three-quarters of a mile south of Abbott Junction, was said to be used primarily to transfer registered packages from the Iowa Central to the Burlington, Cedar Rapids, and Northern Railroad. Smith, however, was skeptical about this. "It is claimed by the postmaster," he wrote, "that they [the packages] pass through this office; I have other information that they do not but that they are simply

${ }^{29}$ For a good account of the turmoil created by fourth-class postmasters see "Rural Free Delivery in Carroll County, Maryland," H. Doc. $691,4-5$. 
held by the agent at the Junction." But whichever way it was, Smith felt this service could be transferred either to the post office at Ackley or the one at Iowa Falls and the Abbott post office abolished. ${ }^{30}$

At Cleves, situated on the Burlington, Cedar Rapids, and Northern Railroad, there was a store, an elevator, a post office, and not much else. At Macey on the Illinois Central Railroad there was nothing except an elevator with a post office inside the elevator office. Smith thought both these post offices could be dispensed with. "I can't see any manner of use for the Cleves Post-Office," he wrote, "except for the merchant and elevator man," and it was obvious he felt the same way about the office at Macey. ${ }^{31}$

Smith planned to run rural routes through the little village of Robertson and one from Alden through Burdette where a small elevator-post office was located. Both of these places were on the Burlington, Cedar Rapids, and Northern Railroad, and with the rural routes going through, neither needed a post office any longer. This was also true of the little crossroads post offices at Hughes, Cottage, and Ellis where new mail routes would be taking the mail directly to the farms in these areas. Furthermore, because some of the rural mail routes planned for Hardin County ran into adjoining counties, Smith thought that the post offices at Ivester in Grundy County and at Bangor in Marshall County, could be abolished. Altogether, Smith believed that twelve little post offices within and without the county could be eliminated. $^{32}$

Though special agents made it a practice to keep their plans to themselves until their work was complete, this was almost always impossible. For if postmasters, townspeople, and farmers did not know exactly what the agent was planning, they could usually make shrewd guesses, and they often made trouble even before the special agent had completed his work. This was the case in Hardin County. Somehow, perhaps because Smith was not discreet enough, certain postmasters apparently heard that Smith considered their post

${ }^{30}$ Smith's Report on Hardin County.

${ }^{31}$ Ibid.

${ }^{32}$ Ibid. 
offices useless, and the Post Office Department was soon immersed in a flood of protests.

Declaring that much time was saved by transferring packages from one railroad to another through his post office, the postmaster at Abbott insisted that his office was absolutely indispensable to a good mail service and may even have gone so far as to accuse Special Agent Smith of collaborating too closely with the postmasters at Ackley and Iowa Falls who wanted the Abbott postal business transferred to their post offices; and this may, indeed, have been the case. And at Macey, the postmaster of the tiny post office in the elevator where perhaps only $\$ 30$ to $\$ 40$ worth of postal business a year was done, tried to show that his post office was necessary in order to secure the stock quotations. ${ }^{33}$

Also aggrieved over the prospect of losing their post office were the people at Cleves, especially the merchant and the elevator man. Word went from Cleves to the Post Office Department giving the impression that Cleves was a thriving metropolis to which a post office was essential, and enough of an uproar was caused over the matter that Smith felt compelled to send the Department a map designating all the houses in the neighborhood in order to show the exact size of the community.

At Bangor, in Marshall County, the prospect of losing the post office and being supplied by a rural mail route from Union roused bitter opposition, and at Ivester in Grundy County, the postmaster and possibly others prevailed upon their Congressman, Robert Cousins, to demand that the post office be continued. ${ }^{34}$

Because of the strong opposition Smith's plans had raised, the Post Office Department detailed two postal inspectors to investigate charges which reflected, as an official report stated, "upon the conduct of Special Agent A. B. Smith and certain postmasters in Hardin County, Iowa" and on June 17 , Smith was recalled to Washington. ${ }^{3 \overline{5}}$

Precisely what took place in Washington is unknown, ${ }^{33}$ Ibid.

${ }^{34} \mathrm{Ibid}$.

${ }^{35}$ Superintendent, Rural Free Delivery to J. L. Bristow, FourthAssistant Postmaster General, June 20, 1901, Hardin County File, N. A. 
but it is likely Smith was shown the mass of complaints from Hardin County; he may even have been warned against working too closely with certain postmasters, and in all probability was cautioned about running roughshod over the interests of the fourth-class postmasters. In any case, it was not until September 16 that he returned to Hardin County to begin work again. Possibly as a gesture of conciliation to injured interests, Smith was now joined in the work by John T. Boylan who in the next two weeks planned the mail routes in the area of New Providence, Hubbard, and Radcliffe in the southern part of the county, and in a portion of Franklin and Butler counties north and east of Ackley. But it was Smith who worked out the rural delivery pattern at Eldora, John Boylan's home town. ${ }^{36}$

By September 30, 1901, Smith and Boylan had completed their job. Altogether they had established forty-one rural mail routes and written little descriptions of each of them such as this one: route 3 at Eldora began at the post office and went southeast to Underwood's 2 miles. . . .

\section{Thence}

East $2 \frac{1}{2}$ and south $2 \frac{1}{2}$ to schoolhouse \#3

miles

East 3 and south 1 to Friend's Church, southwest to corner section 32 Melrose township

West 3 and north 1 to school house \#3

West 1 and south 2 to southeast corner section 2, Union township

West $1 / 2$ and north turning west $7 \frac{1}{2}$ to post office

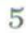

The mail routes averaged 24.94 miles in length, covered an area of 20.73 miles apiece, and served 88.2 houses and a population of 441 persons each. Apparently the heaviest concentration of population in the county in 1901 was in the Ackley area, for the six rural routes radiating from that town served 600 houses and a population of 3,000 , while the seven routes established at Eldora served only 576 houses and a population of 2,880. Even Iowa Falls, with its six routes taking mail to 590 houses and 2,950 people suggested a larger population in this area than that surrounding the county seat at Eldora. ${ }^{38}$

\footnotetext{
${ }^{36}$ Smith's Report on Hardin County.

${ }^{37}$ Route description, Eldora Route, No. 3, Hardin County File, N. A.

${ }^{38}$ Smith's Report on Hardin County.
} 
Indeed, at Eldora and elsewhere through the county, particularly at New Providence, Hubbard, and Alden, the population was rather sparse for rural delivery. According to the Post Office Department's regulations no route was supposed to be established where there was not four houses to the mile, but Boylan and Smith in their anxiety to bring free delivery to every farmer's door, laid out routes in these areas which were far below the standard. For the seven routes at Eldora, for example, there should have been 700 houses instead of 576, and for the five routes at Alden, 500 houses instead of 372 . Furthermore, the whole system was made more expensive than it needed to have been by a network of backtracks where rural carriers doubled back over parts of their routes usually for the purpose of taking the mail directly past a farmer's gate.

Understandably, after all the hue and cry raised against the elimination of post offices, Special Agent Smith finally recommended the discontinuance of but three small post offices-Hughes, Cottage, and Ellis. The Cottage and Ellis Post Offices were very small. Neither was located on a railroad, and before the rural routes had been stretched out around them, both had received their mails by star routes from Iowa Falls. On the other hand, the post office at Hughes was situated on a small railroad, the Chicago, Iowa and Dakota, but there was no station there. The mails were simply thrown off as the train went by, and the postmaster, who was required to meet the trains at all hours, was anxious to get rid of the office. ${ }^{39}$

But everywhere else, at Abbott, Cleves, Burdette, Macey, and Robertson, where there had been trouble, the post offices were allowed to remain with rural mail routes encircling them and giving all the essential postal service that was needed. For the Bangor post office in Marshall County, special arrangements were made so that the post office could stay in business, and the little Grundy County post office at Ivester was allowed to remain because, as Agent Smith put it, "of the express wish of Mr. Cousins that the same remain." ${ }^{30}$

Though Smith and Boylan had completed their work in ${ }^{39} \mathrm{Ibid}$. ${ }^{40}$ Ibid. 
September, there were still rural mail carriers to hire and administrative details to work out, and it was not until November 15 that the new service went into effect-more than a year from the time it had first been promised. But once the new service began and a few adjustments were madeone new rural route was added at Steamboat Rock, for example—it worked so well the farmers could almost set their clocks by the daily arrival of the mailman at their front gates, and as the years passed the old animosities stirred up by the county's irate postmasters subsided. ${ }^{41}$

Elsewhere in the nation the rural delivery system was growing with incredible speed, and by 1905, it had begun to worry postal authorities. In that year there were 32,110 rural mail routes throughout the nation, and every day's mail brought new petitions demanding more rural routes. Each route had been expensive to establish and, with its salaried mail carrier, more expensive to operate. Furthermore, the government was beginning to have budgetary problems, and all in all it seemed to Postmaster General George B. Cortelyou that the time had come to reexamine those routes established when the service was new to see if they could be made more efficient and less costly ${ }^{42}$

Inevitably Hardin County, one of the first in the nation to have a county system, was chosen for possible revisions, and in March, 1906, Peter V. DeGraw, Fourth Assistant Postmaster General, ordered the Chief Postal Inspector to make a general investigation of the county. The Inspector was to recommend "such changes as will result in greater efficiency, or the advisability of discontinuance where it appears the expense involved is not warranted on account of lack of appreciation of the service. ${ }^{43}$

In due course, Postal Inspector J. F. Grote arrived in the county to make the inspection and found all manner of things wrong with the service. Altogether he discovered more than twenty-nine miles of back-tracks, fourteen miles of them on

\footnotetext{
${ }^{41}$ Fourth Assistant Postmaster General to Chief Inspector, Mar. 20, 1906, Hardin County Files, N. A.

${ }^{42}$ Postmaster General's Report, 1905, 90 and 1931, 114. 1906.

${ }^{3}$ Fourth Assistant Postmaster General to Chief Inspector, Mar, 20,
} 
routes out of Eldora and Hubbard alone. Many of the rural mailboxes in the county were not up to standard and neither were some of the roads. The little post offices Smith had allowed to exist still operated side by side with the rural routes, and though the farmers received their mail over the rural routes, many of them mailed their letters at the little post offices merely to help the postmasters build up their cancellation fees. Grote also discovered that the descriptions of the rural routes in the local post offices were not up to date, and as for the number of people being served, almost none of the rural routes was up to the standard of four families per mile. ${ }^{44}$

Certain about what was wrong with the Hardin County mail service, Grote was less certain about the remedy. He regretted that the service had been laid out as it had been and that so many sub-standard routes had been established; for now, he thought, it was virtually impossible to revise the service. "I very respectfully call your attention," he wrote to his superior, "to the fact that wherever the service is now in operation the service is appreciated and any attempt to discontinue the service is met with severe opposition." Because of the Iowa River which could only be crossed at certain points and because of the scarcity of population along the routes, he could not rearrange the routes to take in more patrons without making them so long that a mail carrier could not get around them on a bad day. Nor did he think he could divert a route running past a farmer's gate to a crossroads mailbox a half mile away. "The man who would have to travel $\frac{1 / 2}{2}$ mile after his mail," he wrote, "would at once send in a complaint, and the Department be kept in hot water all of the time." ${ }^{\prime 4}$

Even though the system was inefficient and costly, there were few things that could be done to improve it. The little post offices that had caused Smith so much trouble and which Grote found hindered "the successful growth of the service" could not be eliminated in spite of Grote's recommendations

${ }^{44}$ Report of Inspector J. F. Grote on Hardin County, Iowa, to R. M. Fulton, Inspector-in-charge, Feb. 28, 1907, Hardin County File N. A. Hereafter referred to as Grote's Report on Hardin County.

${ }^{45}$ Grote's Report on Hardin County. 
that this be done. Grote did, however, make minor changes in the routes and also recommendations for improving the roads. Discovering that Thomas Morgan, J. H. Vigars, and W. B. Neeoby at Eldora, Charles Marks at Steamboat Rock, and William Weimer at Radcliffe were responsible for maintaining the country roads, he sent their names to the Post Office Department and urged that they be contacted if the roads became bad in the spring. If this did not help, Grote suggested that the Department discontinue the routes where bad roads existed, for he believed that to stop delivery over one bad road would only deprive one or two families of the service, but to discontinue the route altogether would "bring all the patrons up in arms and roads would be speedily repaired." ${ }^{46}$ Beyond a few small changes in the routes, then, very little was done to change Hardin County's rural mail system until President Wilson became President in 1913 and appointed Albert Burleson Postmaster General.

Postmaster General Burleson, conservative Texan and former Congressman, based his rural delivery policy on at least three considerations; first, he believed that the postal service was a business that should pay for itself; secondly, he discovered that many rural men were using automobiles on their routes, at least in the summertime, and completing their rounds in less than half their horse and wagon time; and finally, as the first Democratic Postmaster General since 1897, he was disturbed by the great number of Republican rural mail carriers who had become entrenched in the service during the Republican years, and who did, indeed, often deliver Republican doctrine on their routes along with the mail. ${ }^{47}$

Acting on these considerations, Burleson and his Fourth Assistant Postmaster General, James I. Blakslee, began a thorough revision of the rural delivery system in 1914. Where it seemed feasible, two horse-drawn routes were merged into

${ }^{46} \mathrm{Ibid}$. and Supplementary Report of J. F. Grote on Hardin County to R. M. Fulton, Inspector-in-charge, Mar. 20, 1907, Hardin County File, N, A.

${ }^{47}$ On Burleson see The National Cyclopedia of American Biography (44 vols.; New York, 1893-1951), XXVIII, 386-87; material on his policies is drawn from the Postmaster General Reports, 1913-1921, the Congressional Record, the Burleson papers in the Library of Congress, and the rural free delivery material in the National Archives. 
one motorized route approximately fifty miles in length. Where this was impossible, the horse-drawn routes were completely rearranged. Some were changed to new roads, some were eliminated, and almost all where lengthened. As a result, Burleson's purposes seemed to have been fulfilled. Where routes were eliminated, money was saved and Republican rural mail men were consequently out of a job. Where routes were motorized, new civil service examinations were declared necessary thereby opening up the possibility of hiring new carriers for these routes and eliminating the necessity of transferring the old carriers, who might be Republican, from the old to the new routes. ${ }^{48}$

In time, revision came, not unexpectedly, to Hardin County. An inspection of the service was ordered there in January of 1915, and by September it was finished. A report from Blakslee to Burleson outlined the results of the revision. No motorized route was established in the county, but seven of the county's forty-two rural routes, including routes 5 and 7 at Eldora, 3 at Ackley, 5 at Iowa Falls, and 3 at New Providence, 1 at Osawa, and 3 at Union, were eliminated. The average length of the remaining routes was increased from 24.95 to 26.5 miles per route, and 252 families were forced to move their mailboxes all the way from one-eighth of a mile to a mile in order to receive their mail on the revised routes. One hundred and two families, however, were given better service than they had had, and most importantly the cost of the entire system was reduced from $\$ 49,656$ to $\$ 41,952$ a year. ${ }^{49}$

The new system went into effect on October 15, 1915 and was almost immediately followed, if indeed it had not been preceded, by angry protests from the patrons and townspeople. The service, it was said, had broken down on the revised routes 2 and 3 at Union because of bad roads and the increased length of the routes. At Iowa Falls, on routes 3 and 5 , patrons who had been compelled to move their mailboxes objected to the distances they now had to go for their

${ }^{48}$ Postmaster General's Report, 1915, 30.

${ }^{49}$ James I. Blakslee, Fourth Assistant Postmaster General to Chief Inspector, Feb. 17, 1915, and James I. Blakslee to Postmaster General, Sept. 1, 1915, Hardin County File, N. A. 
mail. And from New Providence, where some thirty-two families had been discommoded by the elimination of route 3 , came demands for the reestablishment of that route. ${ }^{50}$

The man who received most of these complaints was Burton Sweet, the new Congressman from Iowa's third district. Sweet passed the protests along to the Post Office Department and apparently even called at the Department himself in an attempt to have the situation in Hardin County straightened out. But by February 1916 nothing had been done. "The people," Sweet said, "through their Representatives, have supplicated the head of the department and his assistant, but their supplication has been in vain. The edict has gone forth. The orders are unchanged and apparently unchanging."

Sweet had been elected to Congress in 1914, and being new, was perhaps less able to exert pressure upon the Post Office Department than some of the older Iowa Congressmen like James Good, who made fervent attacks on the administration for tearing up the mail service in Iowa. Nevertheless, Sweet tried. He carried his protests against the rural route revisions directly to the House of Representatives where he won the applause of like-minded members for his attack on the administration's revision of rural free delivery. After explaining how the Post Office Department had changed the service in his district without a thorough investigation and without consulting the people, he said that the people in Iowa wanted only simple justice. He said:

They want an efficient mail service. ... They want the Rural Free Delivery Service improved, extended, and strengthened in every way. If they do not get it during the present administration, I am of the opinion that they entertain a sincere hope that they may get some relief, at least, during the next administration. ${ }^{52}$

Congressman Sweet did induce Blakslee to send an inspector to Hardin County, and in the end, adjustments were made in the service there. The routes at Union were shortened and changed to avoid bad roads, and routes 3 and 5 at

${ }^{50}$ Memo to appointment section, Sept. 3, 1915, and J. K. Pickett, Acting Fourth Assistant Postmaster General to Burton E. Sweet, May 16, 1916, Hardin County File, N. A.

${ }^{51}$ Cong. Record, 64 Cong., 1 Sess., 2733.

${ }^{52}$ Ibid. 
Iowa Falls were re-routed to give better service to some fourteen families. Route 1 at New Providence was also changed to bring the service closer to seven families. However, the principal changes worked out by the Burleson administration in Hardin County remained in spite of the outcries. The postal inspector refused to reestablish route 3 from the New Providence post office, and those who had complained about the service there had to get on as best they could. Of the thirty-two families on old route 3 who had had to move their mailboxes, sixteen were one-quarter, twelve within one-half, and four within three-quarters of a mile of their mailboxes. It was the inspector's opinion that these families were only slightly inconvenienced. ${ }^{53}$

The change of administrations in Washington in 1921 brought a temporary lull in the revision of rural mail systems, and, indeed, the Post Office Department never again revised the service over an entire county at one blow. But year after year, as country roads improved and more and more automobiles were used to bring the mail to waiting farmers, the Department once again began the process of motorizing the rural routes. This time, however, it was done with considerable finesse. In the new order of things the policy was to consolidate two routes only after the rural mail man of one had retired, resigned, or died, and the results of this policy are reflected today in Hardin County. In 1964 the number of mail routes had been reduced from forty-two to eighteen. Only two routes now leave from Eldora where there had once been seven. Ackley and Iowa Falls have only three routes each, and New Providence, where it all began in 1896, has only one. But in spite of the reduction of rural mail routes, the number of miles traveled by the rural mail carriers has actually increased, and the routes that once averaged a little more than twenty-four miles each in 1901, now average well over seventy miles apiece. ${ }^{54}$

${ }^{53}$ James I. Blakslee to Chief Inspector, April 1, 1916, and Report of W. F. Chester, Inspector-in-charge, on Hardin County, May 1, 1916, and J. K. Pickett to Burton E. Sweet, May 16, 1916, Hardin County File, N. A.

${ }^{54}$ Robert G. Carson, Postmaster, Eldora, Iowa to author, n.d. 
Copyright of Annals of Iowa is the property of State of Iowa, by \& through the State Historical Society of Iowa and its content may not be copied or emailed to multiple sites or posted to a listserv without the copyright holder's express written permission. However, users may print, download, or email articles for individual use. 